\begin{tabular}{|c|c||}
\hline Sciendo & $\begin{array}{c}\text { RURAL SUSTAINABILITY RESEARCH 39(334), } 2018 \\
\text { ISSN - 2256-0939 } \\
\text { C Latvia University of Life Sciences and Technologies, } \\
\text { all rights reserved } \\
\text { http://www.llu.lv/en/ }\end{array}$ \\
\hline
\end{tabular}

\title{
Analysis of Precipitation and Runoff Conditions in Agricultural Runoff Monitoring Sites
}

\author{
* Ieva Siksnāne, Ainis Lagzdiņš \\ Latvia University of Life Sciences and Technologies, Lielā street 2, Jelgava, LV 3001, Latvia
}

\begin{abstract}
In order to assess the nature of climate change, it is important to analyze the indicators of climate variability in different scales: spatial and temporal. The analysis at different scales can lead to understanding of the nature of variations. Climate change studies are essential for comprehending the nature of global processes, to refine global climate patterns and also develop further research for natural processes (Meinke, Stone, 2005; Hulme et al., 1999). Processes in nature are united, continuous and in constant interaction. Variance of interaction types are immeasurable, types can be connected with different scales and science fields, for example, biological, ecological, physical etc. If interaction is taking place between the land and atmosphere, it is defined as hydrological interaction. As water is significantly important for many purposes on the Earth, it is relevant to analyze precipitation and water runoff on a local scale. In the territory of Latvia, the amount of precipitation exceeds the level of evapotranspiration. Long-term monitoring data show that precipitation leads to average runoff of $250 \mathrm{~mm}$ per year (Ziverts, 2004). The monitoring data collected at three research sites located in Latvia was used for this research including Berze (Lielupe river basin, meteorological station in Dobele), Mellupite (Venta river basin, meteorological station in Saldus monitoring) and Vienziemite (Gauja river basin, meteorological station in Zoseni). The results from this study show that there is a pronounced interaction between runoff and precipitation with an average of 53 to $82 \%$.
\end{abstract}

Key words: agricultural land, precipitation, subsurface drainage, discharge.

\section{Introduction}

Hydrological interaction between the land and atmosphere is crucial for providing the Earth's functions (Suni et al., 2015). Water circulation is global and affects every water body on the planet including evaporated water in atmosphere. It is unified process affecting water in clouds transformed and transported to land and conversely. Previous research has shown close relationship between meteorological and hydrological conditions. It is expressed by general water balance equation (Rose \& Stern, 1965; Shawul, Alamirew, \& Dinka, 2013):

$P-E T-R-\Delta \mathrm{V}=0$,

where

$\mathrm{P}$ - precipitation $(\mathrm{mm})$,

ET - evapotranspiration ( $\mathrm{mm}$ ),

$\mathrm{R}-\operatorname{runoff}(\mathrm{mm})$

$\Delta \mathrm{V}$ - change in storage $(\mathrm{mm})$.
This equation involves mass conversation principles in a close system, according to which any intake of water into the system in the form of precipitation should be carried by either evapotranspiration, runoff or stored in the ground.

This research aims to evaluate the patterns of precipitation by comparing precipitation data obtained during the long-term and study period as well as the relationships between precipitation and runoff at the monitoring sites.

\section{Materials and Methods}

This research was conducted based on the monitoring data acquired by the Department of Environmental Engineering and Water Management of Latvia University of Life Sciences and Technologies and State Limited Liability Company "Latvian Environment, Geology and Meteorology Centre". The data was obtained at three agricultural runoff

\footnotetext{
* Corresponding Author's email: ieva.siksnaane@gmail.com
} 


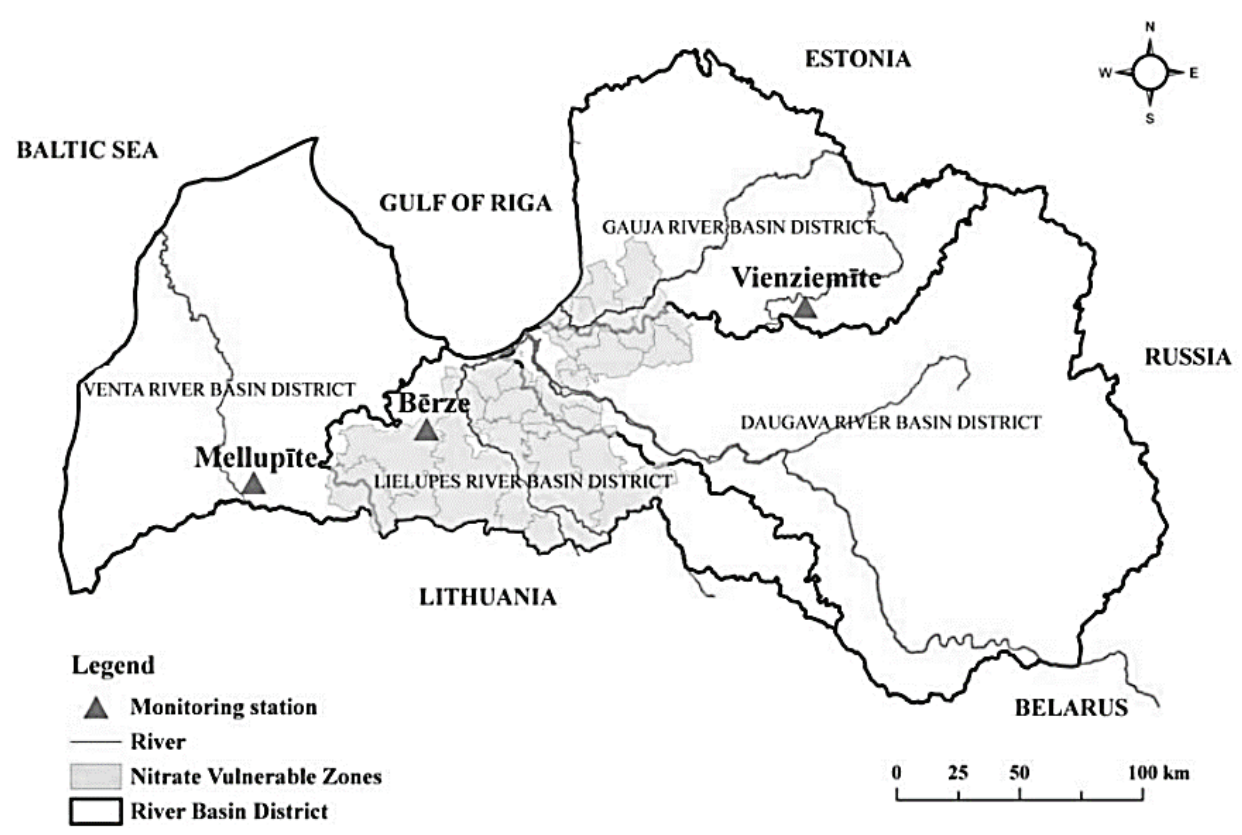

Figure 1. Locations of the research sites.

Source: Geospatial information of LLU and State Limited Liability

Company "Ministry of Agriculture Real Estate".

monitoring sites: Berze, Mellupite and Vienziemite (Figure 1).

The Berze monitoring site is located in the central region of Latvia $\left(56^{\circ} 42^{\prime} 67.57^{\prime \prime} \mathrm{N}, 23^{\circ} 22^{\prime} 78.82^{\prime \prime}\right.$ E). This site is located within the Nitrate Vulnerable Zones designated according to the EU Nitrates directive (European Council, 91/676/EEC, 1991). The Mellupite monitoring site is located in the western part of Latvia $\left(56^{\circ} 29^{\prime} 68.64^{\prime \prime} \mathrm{N}, 22^{\circ} 13^{\prime} 67.13^{\prime \prime} \mathrm{E}\right)$ and the Vienziemite site is located in the north-east part of

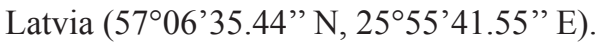

Triangular weirs and pressure transducers were applied to quantify water flow at all subsurface drainage fields monitored at the research sites. The runoff data presented in this study were obtained at subsurface drainage field scale. The time frame of this research lasts from 1995 through 2015. Descriptive statistics were used to describe precipitation and runoff datasets, average values of runoff from a specific area (mm per month) have been calculated based on daily values. The changes in the precipitation patterns between two time periods were explored by comparing the datasets obtained during the long-term (1950 - 1994) and research period (1995-2015).

\section{Results and Discussion}

The analysis of the precipitation data measured for the Berze monitoring site (Table 1) indicates that precipitation during the research period was higher than in the long-term in specific months, i.e., January,
February, March, May, June, October, December with the highest increase stated in July by $28.6 \%$. The amount of precipitation has decreased in April, August and September suggesting that these months might be more exposed to drought conditions than the rest of the year, especially damaging from the agricultural perspective could be the summer months of August and September.

The results for the Mellupite monitoring site are somewhat similar to those observed at the Berze site. At the Mellupite site, the precipitation amounts within the research period are higher in January, March, May, July, August, October with the highest increase observed in February by $23.9 \%$. In contrast, precipitation has decreased in April, June, September, November, and December. The decrease in the precipitation amount in April and September is common for both the Berze and Mellupite research sites.

At the Vieziemite monitoring site, the precipitation during research period was higher than in the longterm data in January, February, March, May, June, December, with the highest increase in October by $22.6 \%$. The amount of precipitation has decreased in April, July, August, November and the highest decrease in September $37.0 \%$.

There are several similar tendencies in the results documented for all three monitoring sites:

1. the amount of precipitation during the research period has increased in January, February, 
Comparison of annual precipitation between two time periods for the research sites

Table 1

\begin{tabular}{|c|c|c|c|c|c|c|c|c|c|}
\hline \multirow{3}{*}{ Month } & \multicolumn{3}{|c|}{ Berze } & \multicolumn{3}{|c|}{ Mellupite } & \multicolumn{3}{|c|}{ Vienziemite } \\
\hline & \multicolumn{2}{|c|}{$\begin{array}{c}\text { Precipitation, } \\
\mathrm{mm}\end{array}$} & \multirow{2}{*}{$\begin{array}{c}\text { Difference* } \\
\%\end{array}$} & \multicolumn{2}{|c|}{$\begin{array}{c}\text { Precipitation, } \\
\mathrm{mm}\end{array}$} & \multirow{2}{*}{$\begin{array}{c}\text { Difference* } \\
\%\end{array}$} & \multicolumn{2}{|c|}{$\begin{array}{c}\text { Precipitation, } \\
\mathrm{mm}\end{array}$} & \multirow{2}{*}{$\begin{array}{c}\text { Difference* } \\
\%\end{array}$} \\
\hline & $\begin{array}{c}1950- \\
1994\end{array}$ & $\begin{array}{l}1995- \\
2015\end{array}$ & & $\begin{array}{l}1950- \\
1994\end{array}$ & $\begin{array}{l}1995- \\
2015\end{array}$ & & $\begin{array}{r}1950- \\
1994\end{array}$ & $\begin{array}{l}1995- \\
2015\end{array}$ & \\
\hline January & 31.7 & 39.2 & 23.7 & 42.0 & 50.4 & 19.9 & 49.6 & 54.0 & 8.9 \\
\hline February & 24.7 & 30.0 & 21.4 & 29.0 & 35.9 & 23.9 & 36.6 & 44.3 & 21.1 \\
\hline March & 26.7 & 30.0 & 12.4 & 34.4 & 36.9 & 7.2 & 37.3 & 39.0 & 4.6 \\
\hline April & 42.7 & 30.4 & -28.9 & 40.2 & 39.8 & -1.0 & 47.0 & 40.1 & -14.6 \\
\hline May & 40.1 & 48.3 & 20.5 & 41.6 & 50.8 & 22.2 & 54.1 & 64.5 & 19.2 \\
\hline June & 51.6 & 66.2 & 28.3 & 60.7 & 58.9 & -2.9 & 70.8 & 82.0 & 15.8 \\
\hline July & 68.5 & 88.1 & 28.6 & 76.6 & 83.2 & 8.7 & 80.4 & 80.0 & -0.4 \\
\hline August & 75.6 & 66.8 & -11.6 & 74.8 & 91.0 & 21.7 & 88.6 & 70.7 & -20.2 \\
\hline September & 59.6 & 49.2 & -17.5 & 69.4 & 58.9 & -15.1 & 77.9 & 49.1 & -37.0 \\
\hline October & 53.3 & 66.4 & 24.5 & 66.6 & 76.3 & 14.6 & 67.1 & 82.3 & 22.6 \\
\hline November & 52.1 & 44.4 & -14.8 & 62.9 & 51.0 & -18.9 & 64.6 & 59.7 & -7.6 \\
\hline December & 39.8 & 40.9 & 2.8 & 54.1 & 48.9 & -9.5 & 56.4 & 58.6 & 4.0 \\
\hline
\end{tabular}

*difference between time period 1950-1994 and 1995-2015

March, May, July and October when compared with the long-term;

2. during the research period the precipitation has decreased in April, September, October, and November;

3. the mean annual precipitation during the research period has been considerably higher than during the long-term;

4. the difference between the long-term data and the data obtained during the research period allows to make predictions about precipitation variances in the future periods.

Previous study has concluded that there is a strong relationship between annual precipitation and runoff at several research sites in the Nordic-Baltic countries (Oygarden et.al., 2014). To determine the relationship between annual precipitation and runoff for Latvian research sites, a correlation and regression analysis were applied.

The correlation analysis between the annual precipitation and runoff for the research period of 1995 - 2015 indicated that the correlation coefficients for the Berze, Mellupite, and Vienziemite research sites were 0.75 (positive, close relation), 0.82 (positive, close relation), and 0.53 (positive, average relation), respectively. This showed that for every positive increase of one variable (annual average precipitation) there is a positive increase of the other variable (annual average runoff). It has to be mentioned that correlation analysis may only provide some indications of the relationship between daily precipitation and runoff as precipitation results in runoff with a time lag depending on the texture of soils at the research sites.

Regression analyses indicates variability of the response data around its mean, the results of regression analyses summarized in Figure 2.

For the Berze monitoring site R-squared (determination coefficient) value is 0.57 , while for the monitoring site Mellupite 0.67 and the monitoring site Vienziemite 0.28 , which indicates that variability of the response data around its mean in this research are $56.53 \%, 67.14 \%$ and $28.31 \%$.

The data from the Berze monitoring site (Figure 3) shows tendency that in different season relation between precipitation and runoff amount is similar. In summer precipitation level is increasing and runoff is decreasing, in winter months on the contrary precipitation level is decreasing and runoff is increasing. In spring time runoff level is decreasing and precipitation level is exceeding and in autumn runoff is increasing and precipitation level is decreasing.

For the Mellupite monitoring site precipitation and runoff (Figure 4) tendency is similar to the Berze monitoring site: in summer and spring precipitation level increases while runoff amount is decreasing, in winter and autumn on the contrary. 


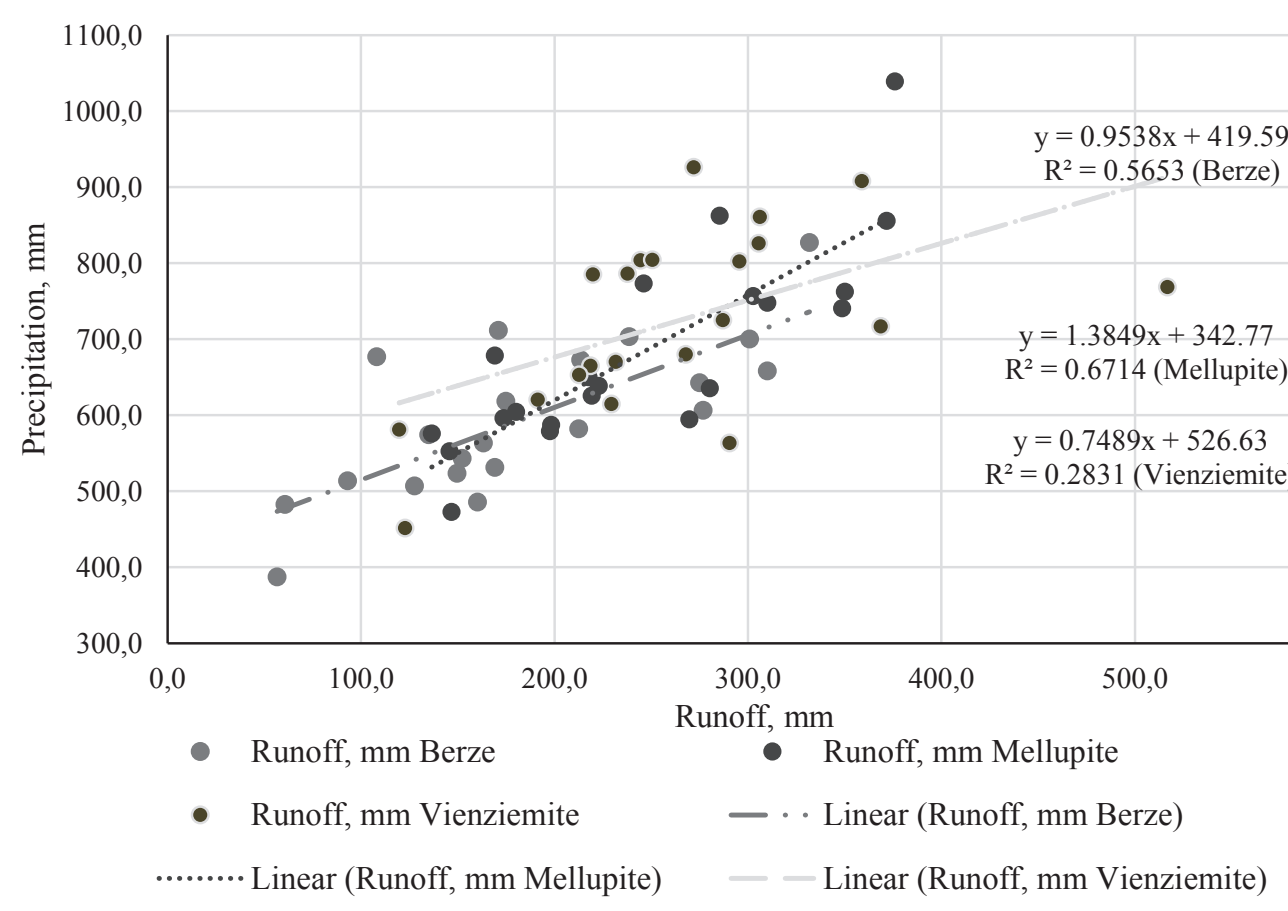

Figure 2. Regression analyses of precipitation and runoff data for the monitoring sites.

Source: State limited Liability Company "Latvian Environment, Geology and Meteorology Centre" and Latvia University of Life Sciences.

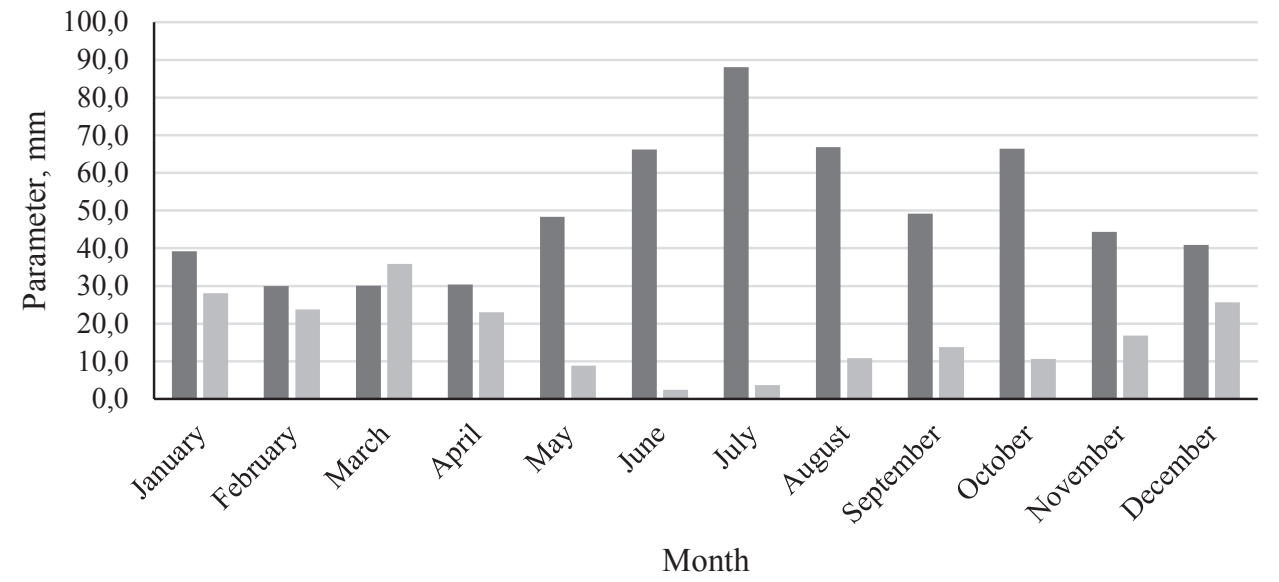

• Precipitation, mm 1995-2015 —Runoff, mm 1995-2015

Figure 3. Average annual precipitation and runoff for the Berze research site.

Source: State limited Liability Company "Latvian Environment, Geology and Meteorology Centre" and Latvia University of Life Sciences.

At the Vienziemite monitoring site precipitation and runoff (Figure 5) data analysis confirms previously stated conclusions.

Similar studies showed that in winter months (December, January, February) precipitation is accumulated in the form of snow and therefore runoff subceeds precipitation (Regonda \& Rajagopalan, 2005; Nielsen \& Hansen, 1973), while in spring
(March, April, May) snow is melting and runoff exceeds precipitation level (Nielsen, Hansen, 1973). In summer (June, July, August), the runoff amount decreased as evapotranspiration rate exceeds precipitation (Apsite et.al. 2017; Teuling et al., 2013).

Previous research on the Vienziemite monitoring site showed that in the future maximum discharge will change from spring to winter months (Apsite et.al. 


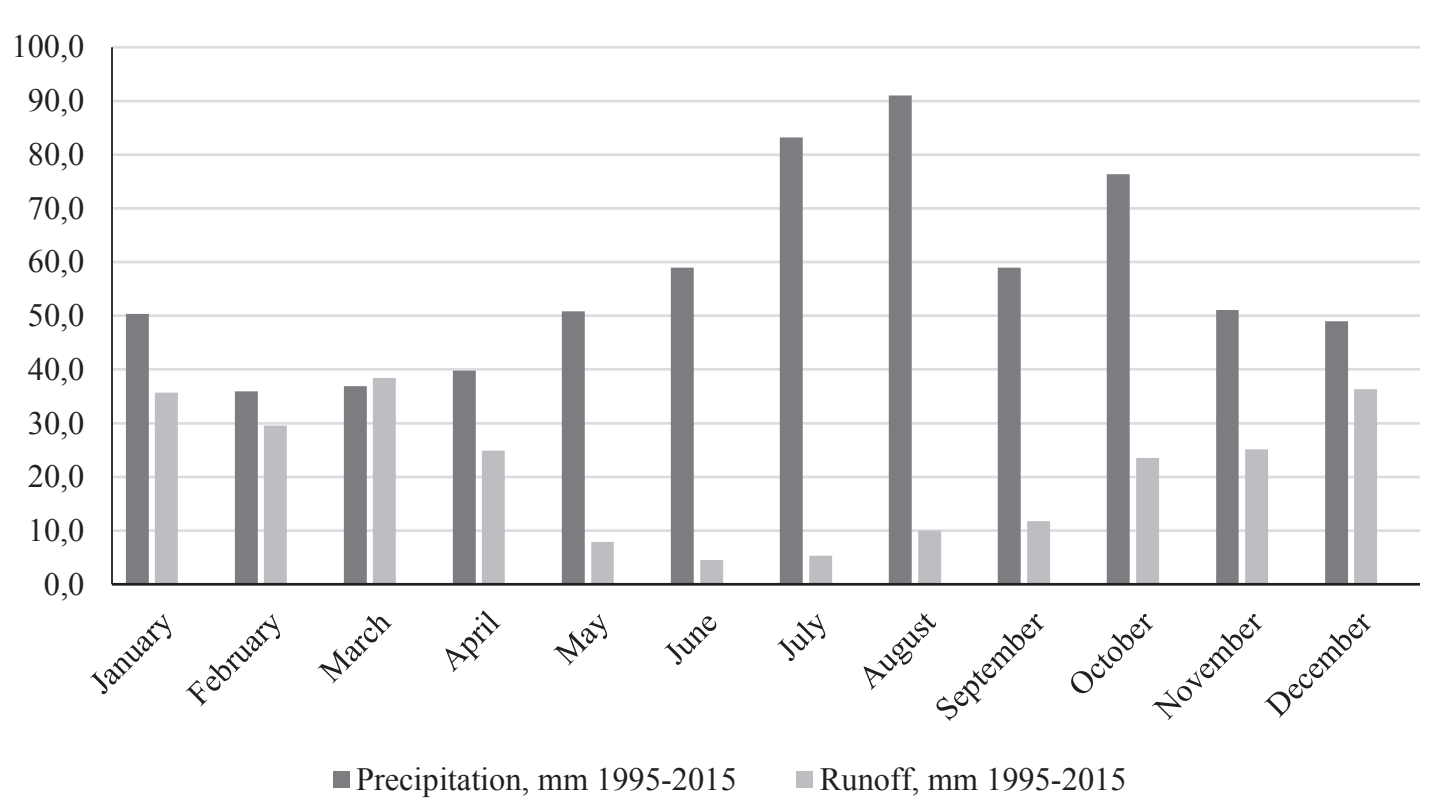

Figure 4. Average annual precipitation and runoff for the Mellupite research site.

Source: State limited Liability Company "Latvian Environment, Geology and Meteorology Centre" and Latvia University of Life Sciences.

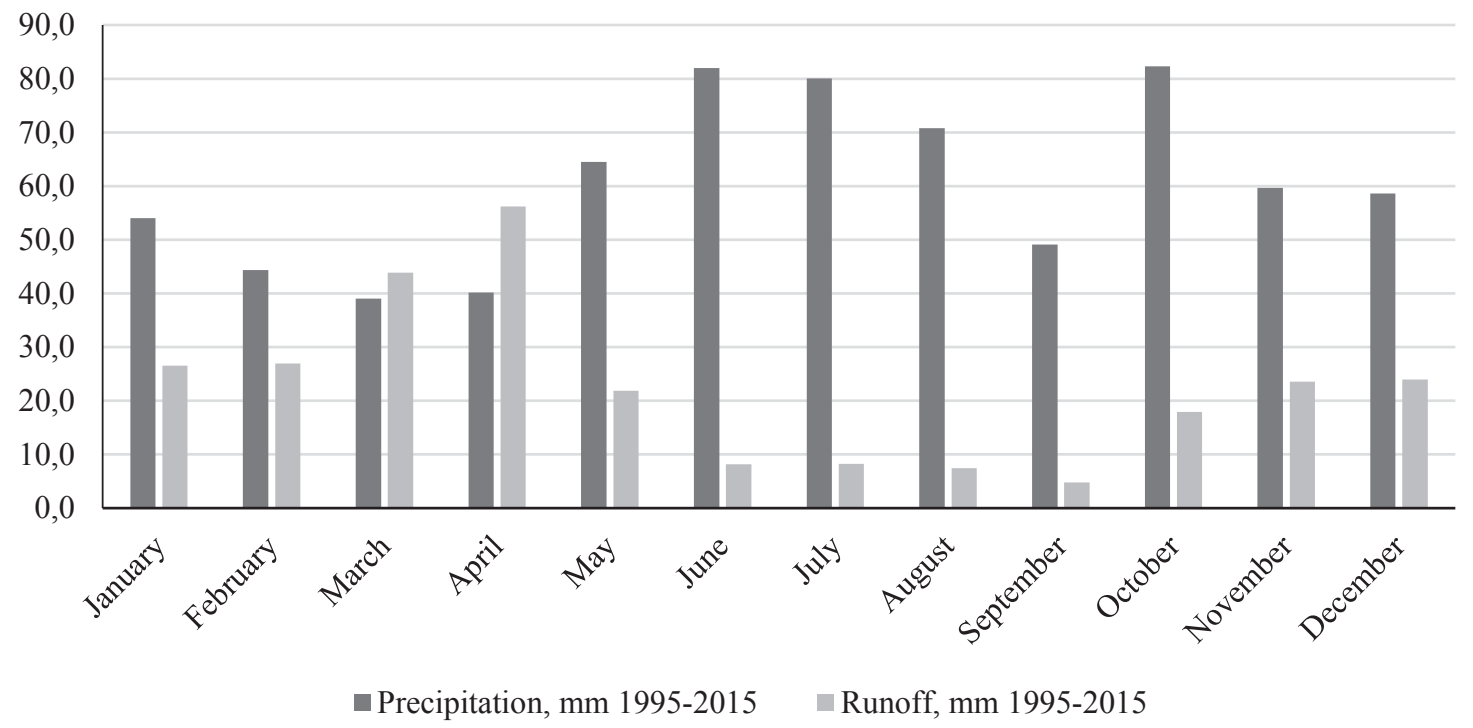

Figure 5. Average annual precipitation and runoff for the Vienziemite research site.

Source: State limited Liability Company "Latvian Environment, Geology and Meteorology Centre" and Latvia University of Life Sciences

2017). Overall, the results from this study as shown in Figure 3, Figure 4, Figure 5 agree with the results of another studies described earlier in this paper.

Relation between runoff and water quality is proved in previous research (Merrington et al., 2002; Havlin et al., 2005; Sileika et al., 2005). Identification of meteorological and hydrological conditions is the initial stage of further analysis of nitrogen and phosphorus losses with drainage water.

\section{Conclusions}

This research showed that the amount of precipitation during the long-term (1950-1994) is considerably different from the research period (1995-2015) which most likely is an evidence of climate change. In addition, this study provides a validation for mutual interactions between average annual precipitation and runoff, with relatively close relationships as the correlation coefficients for the 
Berze, Mellupite, and Vienziemite research sites were $0.75,0.82$, and 0.53 , respectively.

It can be concluded that for all three monitoring sites the amount of precipitation and seasonal variation considerably affect the formation of runoff when the soil profile is saturated with water, while during the vegetation period probability that runoff is caused by precipitation is low.

\section{References}

1. Apsite, E., Nikodemus, O., Brūmenis, G., Lagzdins, A., Elfers, D., Randenieks, Z. \& Klints, L. (2017). Impact of Climate Variability, Drainage and Land-cover Changes on Hemiroboreal Streamflow. Hydrological Sciences Journal 62, 2558-2570.

2. European Council. (1991). Directive 91/676/ EEC concerning the protection of waters against pollution caused by nitrates from agricultural sources. Official Journal of the European Union. $375,1-8$.

3. Havlin, J. L., Beaton, J. D., Tisdale, S. L. \& Nelson, W. L. (2005) Soil Fertility and Fertilizers: An Introduction to Nutrient Management. Upper Saddle River, Pearson Education, Inc., 515.

4. Hulme, M., Barrow, E.M., Arnell, N.W., Harrison, P.A., Johns, T.C. \& Downing T.E. (1999). Relative Impacts of Human - Induced Climate Change and Natural Climate Cariability. Nature 397, 688-691.

5. Meinke, H., Stone, R.C. (2005). Seasonal and Inter-Annual Climate Forecasting: The New Tool for Increasing Preparedness to Climate Variability and Change in Agricultural Planning and Operations. Climatic Change 70, 221-253.

6. Merrington, G., Winder, L., Parkinson, R. \& Redman M. (2002) Agricultural Pollution: Environmental Problems and Practical Solutions. Taylor \& Francis, 243.
7. Nielsen, S.A. \& Hansen E. (1973). Numerical Simulation of the Rainfall - Runoff Process on a Daily Basis. Hydrology Research 4, 171-190.

8. Oygarden, L., Deelstra, J., Lagzdins, A., Bechmann, M., Greipsland, I., Kyllmar, K., Iital A. (2014). Climate Change and the Potential Effects on Runoff and Nitrogen Losses in the Nordic-Baltic Region. Agriculture, Ecosystems and Environment 198, 114-126.

9. Regonda, S.K. \& Rajagopalan, B. (2005). Seasonal Cycle Shifts in Hydroclimatology over the Western United States. Journal of Climate 18, 372-384.

10. Rose, C.W. \& Stern, W.R. (1965). The Drainage Component of the Water Balance Equation. Australian Journal of Soil Research 3, 95-100.

11. Shawul, A.A., Alamirew, T. \& Dinka M.O. (2013). Calibration and Validation of SWAT Model and Estimation of Water Balance Components of Shaya Mountainous Watershed, Southeastern Ethiopia. Hydrology and Earth System Sciences 10, 13955-13978.

12. Sileika, A. S., Gaigalis, K., Kutra, G. \& Smitiene A. (2005) Factors affecting $\mathrm{N}$ and P losses from small catchments (Lithuania). Environmental Monitoring and Assessment, Vol. 102, 359-374.

13. Suni, T., Guenther, A., Hansson, H.C., Kulmala, M., Andreae, M.O., Arneth, A., Seneviratne S. (2015). The Significance of Land-atmosphere Interactions in the Earth System - iLEAPS Achievements and Perspectives. Anthropocene 12, 69-84.

14. Teuling, A.J., Loon, A.F., Seneviratne, S.I., Lehner, I., Aubinet, M., Heinesch, B., Spank, U. (2013). Evapotranspiration amplifies European summer drought. Geophysical Research Letters 40, 2071-2075.

15. Ziverts A. (2004). Hidroloǵija (Hydrology). Latvia University of Agriculture. Jelgava: LLU. (in Latvian). 